International Journal of Advanced Academic Research (Business and Economic Development) | ISSN: 2488-9849

Vol. 6, Issue 12 (December, 2020) |www.ijaar.org

Journal DOI: 10.46654/ij.24889849

Article DOI: 10.46654/ij.24889849.b61214

\title{
COMPETITIVE PARITY AND MARKETING PERFORMANCE OF NIGERIA BREWERIES PLC
}

\author{
Nwaohiri Maximus Onyema \\ Management Department, \\ University of Port Harcourt Business School, \\ Port Harcourt, Rivers State. \\ B. Chima Onuoha \\ Department of Management, \\ University of Port Harcourt, Choba, \\ Rivers State, Nigeria.
}

\begin{abstract}
Nigeria, just like most alcohol drinking countries around the world, is in the middle of a brutal beer war that has seen competing beer makers suffer declining bottom lines in exchange for higher market share. In Nigeria, this battle is currently between three major brewers: International Breweries, Guinness Nigeria and Nigeria Breweries. Keen competition among producers in the breweries industry had led to the search for production strategy and cost management technique to survive and outwit competitors. These goals, strategies and techniques are known as competitive parity. In the light of this, the study evaluates the competitive parity and marketing performance of Nigeria Breweries Plc in Nigeria amidst the stiff competition from other formidable beer brands. The paper derives its justification from the stiff rivalry that has characterized the high promotion war amongst firms in the industry, and the attendant tendency of adversaries. The competition amongst firms in an industry is identified as bearing on a contest to gain brand superiority, thereby shifting emphasis to place and promotion utilities of the marketing mix. The study relied on extant literature survey to identify strategic and tactical imperatives for survival of firms in the industry. It contended that defensive strategies and PEST analysis are sine quo non for competitive intelligence to sustain realistic and impactful existence in the highly competitiveness in the world of breweries in Nigeria.
\end{abstract}

Keywords: Competitive parity, competitive advantage, marketing success, brand superiority, marketing mix, competitive intelligence, strategic marketing. 


\section{INTRODUCTION}

The present day manufacturing environment embodies products with various substitutes in every product line. This has provoked grave competition among firms in the same or similar industry (Ghafeer, Abdul-Rahman, \& Mazahrih, 2017). The local manufacturers in Nigeria are not only competing in the home restricted market but also against firms in the same industry in the global arena. The competition became tough with the presence of foreign products from western manufacturing giants that are cheaper and of higher quality. The quality and cost advantage of the foreign products emanates from the level of technological innovation, and the use of advanced strategies and tools in both manufacturing process and product strategic techniques (Hussein \& Sulaiman, 2017). The differential cost and quality between local products of different firms on one hand and foreign made products on the other hand has influenced meaningful changes in customers' demand. In Nigerian breweries industry, the competition is stiff as every product line whether alcoholic, beverages or foods have multiple close substitutes. The unprecedented level of competition in the industry in Nigeria among firms has assumed an ugly dimension which has also become a threat to the manufacturing sector of the economy in which breweries play significant roles.

Razaq (2010) noted that Nigerian Breweries Plc and Guinness Nigeria Plc have for ages dominated the market. However, the tune of event took a different turn as the major brewers in advanced countries have identified Nigeria as a growth frontier. SABMiller made a strategic entry into the brewery market in Nigeria in 2008 through the acquisition of effective interest of $57 \%$ in Pabod Breweries Limited and $80 \%$ in Voltic Nigeria Limited using Standard Breweries Limited as launching pads. While SABMiller is yet to boil up competitive pressure, the presence of Castel, another global brewery giant with rich African experience came into the market with one of the international premium brands, Castle Milk Stout. Castel later acquired majority stake in International Breweries Plc to solidify its presence in the Nigerian market. In a similar dimension, Carlsberg, the fourth largest brewer in the world, made a leveraged entry into the Nigerian market by sealing partnership agreement with International Breweries Plc for the production and marketing of its notable trademarks - Kronenbourg Beer and Wilfort Stout. According to Razaq (2010), Guinness has been in Africa since the early 19th century and has been brewing in Lagos for more than 50 years while Nigerian Breweries Plc has a very rich Nigerian experience with an extensively solid distribution platform and a successful strong customer base.

Therefore, ceding of significant market share already gained over the years to the new entrants will be gradual. This is because the volume of market share and brand positions of Guinness Nigeria Plc and Nigerian Breweries Plc are strong hurdles to cross. All the same, these new entrants infuriate the sector and steamed up the level of competition which has significant influence on consumers' behaviour. The intense economic rivalry among firms in the industry has negatively affected all aspect of the business - individual firm's sales volume, industrial market share and bottom-line (Subhash, 1994; Ghafeer et al., 2017). This scenario has raised a major question of whether or not there is any tool within the management accounting discipline that can be employed to moderate the key parameters influencing competition variables. These variables include cost of production, pricing policy, quality of goods and customers satisfaction, 
and efficient product delivery service. In order to deal with these issues, government adopted some economic policies in favour of local manufacturing firms such as increased tariff on imported goods and the outright import prohibition were necessary. Sometimes, tax holiday is used as a means of encouraging local firms (Imeokparia \& Adebisi, 2017). Breweries companies on their own have also continued to search for strategies, models and business tools to survive and beat the competition (Maskell \& Baggaley, 2003). In order for any adopted product strategic techniques to be termed efficient, it must be able to address competitive pricing, effective costing, product quality and the achievement of the desired profit level (Adeniji, 2017).

To be locally and internationally competitive, a firm apart from maximising the critical role of branding and advertising to match competitors' brands, using appropriate distribution network, and expanding its production capacity, pricing and cost structure are of utmost importance. These two critical competitive success factors are the core values of competitive parity. Implementation of competitive parity is one of the effective internal strategic management technique within the control of the management that determines the success of any manufacturing organization (Clifton, Bird, Albano \& Townsend, 2004). This strategic technique allows for a proactive strategic planning and management at product design and development cycles. It encourages market orientated product price and demand flexibility (Al-Awawdeh \& Al-Sharairi, 2012; Olabisi \& Dafe2017). Competitive parity is implemented by firms in order to increase sales volume, retain or expand industry market share, and achieve the desired profit level (Maskell \& Baggaley, 2003; Ghafeer et al., 2017).

\section{Statement of Problem}

Amid several industry challenges faced by beer makers in the country such as stiff competition making it difficult for a price increase, sluggish economic growth which has left consumers cashstrapped, and increase in excise duties, Nigerian Breweries like other beer company have to determine the best marketing mix to retain and advance its market share. The problem brewery industry is facing has to do with cost of living, pressures from foreign exchange rates, decreasing in disposable income, security concerns which affects distribution, infrastructural development, high cost of obtaining funds, high cost of acquiring industrial machine, Inadequate government support for industrialization drive of small and medium entrepreneurs (Ghafeer et al., 2017). There is scanty study on how competitive parity has helped companies in Nigeria, especially in brewery industry, it is therefore important to ascertain how Nigeria Breweries Plc has used competitive parity method to its advantage in the industry. Therefore, the main thrust of the study is to determine how competitive parity method impacted marketing success of Nigeria Breweries Plc.

In this study, the researcher structured the remaining parts of this article as follows: first, the conceptual, theoretical and empirical review on competitive parity and competition and their sub variables. Second, hypotheses development and the statement of model of analysis structured in line with the examination. Third, the methodological specification using a case study research approach to illustrate the application of the model of analysis in the breweries industry explicit context. Finally, data analysis, presentation, interpretation and discussion of funding. 
Contribution of the article along with the managerial implications and suggestions for future research was also presented.

\section{REVIEW OF LITERATURE}

\subsection{Conceptual Review}

Competitive parity means the ideal expenditure on branding and advertisement in order to stay at par with rivals in the market (Kumar, 2017). The budgetary allocation, is based on analysis of optimum level of the competition in the market place. This is more of a defensive mechanism used by companies to defend their brand name and position themselves in the market place, without overshooting their budget. Adeniji (2017) posits that most companies worldwide, before entering a market do market analysis before entering. For instance fast moving consumer goods like the Coca cola and Pepsi, budget towards promotional activities mainly to match competition. A key merit for this strategy is that the company will be close to their market competitors spend, on promotional activities and will also sell the company to their yet-to-be customers. At the end of the year, when businesses prepare their budgets, cost and revenue projection will most of the time depend on the previous year's performance. In this case, it is pretty straight forward, as you will budget against other company's budget and try to match theirs. But the question is, if you're a market Leader, naturally, other businesses will depend on you to show your promotional budget, before they complete theirs. The demerit here is where companies are new and may not be very strong in a sector,there is a possibility that they may incur huge losses, when trying to match cost allocation to advertisement as compared to stronger companies who are doing well. Also spending the same amount of money towards advertising does not guarantee same outcome (Ellarm, 2006; Jalaee, 2012).. for the application of competitive parity to work perfectly in any organization, it should be supported by the senior management.Maria (2012) noted that there are six major principles that provide the conceptual foundation upon which competitive parity focuses. These include market price orientation, price based costing, consumers and product design support, multidisciplinary team work, product life cycle, and entire value chain involvement.

\subsubsection{The tools of competitive parity}

The tools of competitive parity include (i) Value engineering: This is the mechanism used for a systematic analysis of a product's design, materials specifications, and production process in the context of customers' needs. It helps to balance the overall costs and benefits and increase the ultimate value of a product ((Institute of Management Accountants, 1994). Value engineering method is used for improving the "value" of a product through the examination of function. Value, means the ratio of function to cost, therefore value can be increased either by improving the function or reducing the cost. (ii) Lean manufacturing:This is an organized method for the elimination of waste - Muda within a manufacturing system. It enables a manufacturer to eliminate waste and non value work to achieve efficiency and customer satisfaction. Lean method considers waste created through overburden - Muri and those emanating from unevenness in workloads - Mura. Lean production enables the the producer to eliminatewaste, minimizes cost and produce and sell product at a competitive price. (iii) Supply chain 
management: This refers to the entire network of the companies that support the management of the flow of goods and services. It includes the storage and movement of raw materials, work-inprocess, and finished goods inventory from point of origin to place of consumption. It enhances prompt delivery of goods to final consumers. Effective supply chain management would make goods available at market place which is the competitive enironment. (iv) Kaizen philosophy: This is an original Japanese management concept which supports continuous product and process improvement. The enhancement is usually incremental (gradual and continuous) to effect change (improvement). It focuses on using employee creativity to help define the way of improving procedures, systems, processes and products. Kaizen philosophy is mostly effective immediately after a new part is designed but before the manufacturing process begins.

\subsection{Theoretical Review}

The foundation of this study is supported by compettve party theory. Ths theory refers to the optimal expenditure needed on branding and advertising activities to stay on par with the competitors of a particular brand, product or company as a whole. Although this theory does not always prove accurate in practice, it is used within numerous companies to argue in favour of investing more in advertising. Followed by this is the pricing strategy theory which describes the relationship between product cost and profit under competitive environment. The theory states that price is the only element in the marketing mix that produces revenues while all other components represent costs. Therefore, choosing the right price for a product especially when it emanates from customers' ability to pay helps send the appropriate price-quality signal which has moderating effect on the sales volume and profitability (Kaur, 2017). The theory is centred on three main points: cost and profit objectives, consumers' demand, and competition. In pricing, the factors to be considered include target group and willingness to pay, costs to be incurred, level of competition, company objectives, and the proposed positioning strategies. Pricing may be cost-based, demand-based or competition-based. In cost-based pricing, prices are set based purely on production costs and the desired profit without considering the demand. In demandbased pricing, consumer research helps to ascertain the acceptable price range, then profit and cost requirements are determined within that range. In competition-based pricing, prices are set based on competitors' price. Depending on customer loyalty, or brand differences, selling price might be above or below the market price. This is where competitive parity becomes useful to the adaptors.

\subsection{Empirical Review}

The empirical studies captured in Nigeria include: Adeniyi (2017) who conduct a study to ascertain the impact of competitive parity on competitive advantage in Nigeria manufacturing firms. The study concluded that competitive parity enhance cost and quality advantage in competitive manufacturing industry. Idowu (2017) examined competitive parity and competition in the manufacturing industry in Nigeria. The research report indicated that competitive parity enhances cost minimization and increases sales volume leading to competitive advantage in manufacturing industry, despite some teething problems encountered by firms in adopting the technique. Imeokparia and Adebisi (2017) explored the extent of competitive parity system adoption and implementation by manufacturing firms in South-Western Nigeria and the impact 
on their performance. It was concluded that there is a significant relationship between adoption of competitive parity and cost reduction on one hand and improvement in return on investment on the other hand. However, it was noted that the level of adoption and application of competitive parity was low in the region. Olabisi and Dafe (2017) investigated the relationship that exists among competitive parity technique and turnover and profitability of small and medium scale enterprises in Ogun industrial metropolis. The result of the analysis indicated that competitive parity technique has statistical significant relationships with annual turnover as well as profitability of SMEs in the area. The study therefore, concluded that implementing a competitive parity technique would enhance sales and profitability of SMEs in Ogun industrial metropolis in Nigeria.

Other researchers who studied competitive parity outside Nigerian environment were also considered in order to have a robust atmosphere for discussion and conclusion. These include: Dekker and Smidt (2003) who conducted a survey on the relationship between the adoption of competitive parity method and the intensity of competition of Jordanian and other Arab companies. Findings revealed that the global competition has led to the withdrawal of some companies from the market and forced others to apply modern methods of costing. Murat, Kadir, and Mehmet (2009) examined the application level of competitive parity among the Turkish manufacturing enterprises. Findings indicated that the companies applying competitive parity had extensive market analyses and excellent marketing information system. It was concluded that competitive parity had significant relationship with competitive advantage as it allows for a balanced competition strategies. Briciu and Capusneanu (2013) studied the pros and cons for the implementation of competitive parity method in Romanian household appliances manufacturing entities. The critical success factors were analyzed and the results show that there is possibility of adopting and implementing competitive parity method in the manufacturing sector in Romania due to its long term benefits. Hussein and Sulaiman (2017) studied the adoption of competitive parity in Malaysia. The finding shows that it is required to enable organizations deal with challenges and problems of today's competitive environment where many companies are continuously seeking to produce high quality and functional products based on customers' expectations gleaned from market research.

In another study, Henrik and Gustav (2003) investigated the extent to which Swedish manufacturing companies use competitive parity. Through random sampling, 250 companies were selected and contacted by telephone, and were asked if they would participate in a survey located on a web site. The number of answers received was 91, representing a response rate of $36.4 \%$. The result from this survey shows that insignificant porportion of Swedish manufacturing firms (16.5\%) is using competitive parity. The findings indicated that firstly, lack of knowledge about competitive parity was responsible for many companies not adopting the practice. Secondly, Swedish manufacturing companies using competitive parity were the large ones which have a differentiation strategy and operate in highly competitive environments. The study concluded that there was a significant relationship between competitive parity and competition. Sulayman (2017) evaluated the adoption of competitive parity approach in manufacturing companies in Jordan. The result indicated that manufacturing companies in Jordan applies the requirements of competitive parity for obvious advantages. Some of the benefits discovered include: cost reduction, customers' satisfaction, quality control, efficient 
pricing decisions, and application of team work approach. However, they noted that the obstacles inhibiting the adoption of competitive parity technique in Jordan were tediousness, costly information gathering, data analysis, as well as lack of management support. Baharudin and Jusoh (2015) conducted a research on target strategic management (TCM) as Japanese companies' competitive tool. The purpose of the paper was to explore how the TCM was being practiced and the major factors influencing the method in non-Japanese environment. The study finding shows that although the fundamental concept is similar, there are differences in details processes due to the adaptation with the contextual constraints. The specific gaps indentified from the previous studies reviewed, indicates that some of the sub variables supporting competitive parity and performance were not studied while others were poorly examined. To the best of this researcher's knowledge, no study has been carried out on the impact of competitive parity on competition in the breweries industry in Nigeria. Therefore, this study is conducted to bridge these gaps and contribute to knowledge.

\section{Methodology}

\section{- Research design and population}

This research employed the case study method as suggested by Yin (2003) and Norhafiza and Ruzita (2015). Since no study had been conducted on competitive parity and marketing success in breweries industry in Nigeria, a case study was deemed appropriate for more specific and relevant data to be collected. It also allowed the whole subsector to be deeply investigated as suggested by Norhafiza and Ruzita (2015). The sample case is Nigerian Breweres Plc. Data was collected through the use of secondary sources like annual reports and company periodicals.

\section{- Profiles of Nigeria Breweries Plc}

Nigeria Breweries Plc was Nigeria's first brewery company and started production in June, 1949 when they rolled out the first bottle from their Lagos brewery bottling lines. It was in 1946 that United African Company (UAC) International UK, and Heineken of Holland signed a contract to incorporate this company then known as "Nigeria Breweries Ltd". It was with the coming into effect of companies and allied matter's act of 1990 that their name was changed to "Nigeria Breweries Plc" to reflect their being quoted at the Nigeria stock exchange as a Public Limited Liability Company. However, when they started, the foreign ownership was $100 \%$. In the early1950s, when its business operations kicked off fully, few homegrown traders were as a matter of strategy invited to be part of the company, and were made shareholders. The indigenization policy of 1970 s, tells that, foreign shareholding are to relinquish a substantial portion of their shareholding to Nigerians. Nigeria Breweries Plc has an ownership structure of 60:40 Nigeria and foreign ownership respectively. The company first produced Star Lager beer, and brought out different bottling lines of its Lagos Brewery in June 1949. The Company expanded and commissioned other branches, which included the Aba Brewery in 1957, in 1963 they opened Kaduna Brewery, in 1982 they opened Ibadan. It also acquired its fifth brewery in Enugu state, by September 1993. The sixth brewery was located in the same state, at Ama Enugu in October 2003. Interestingly, this Brewery at Ama Enugu became the largest brewery in Nigeria and was one of the most modern worldwide. By 2004, the brewery at Enugu was closed 
down, reducing the number of their breweries to five. This market Leader had a line-up of highquality brands, e.g Gulder lager beer launched in 1970, the Star (1949); and then Maltina (1976), which now are of three types Maltina Classic, Maltina Strawberry, and Maltina with Pineapple. Maltina Sip-it (2005), was also re-packaged in Tetrapaks; Legend Extra Stout (1992); and Amstel Malta (1994). In 1998, Nigeria Breweries Plc re-introduced into the market, the Heineken Lager to capture market share. It is pertinent to mention that as a market leader, Nigeria Breweries Plc, became quoted on the Nigeria stock exchange (NSE) and was the most capitalized brewery company in Nigeria.

\section{RESULTS AND DISCUSSIONS}

In this paper analytical premium is given to Nigeria Breweries Plc, which is the largest brewery in Nigeria. The analysis involved the use of high-performance strategies like PEST and SWOT, to place the firm on analytical scale, to provide understanding of its marketing performance.

\section{The Market Environment}

Macro and micro markets are the external and internal areas where Nigeria Breweries Plc play, and two models PEST analysis and Porters Five Forces model, will be appropriate in discussing how the Nigeria Breweries Plc have weathered the storm to become a market leader. PEST analysis is a useful tool in ascertaining why a business grows and why it declines, as this will guide top Management with market knowledge, and help them relate with market information provided by middle and lower management. As this will assist in proper decision making that would better position their company. 'PEST' stands for Political, Economic, Social, and Technological factors which are used to assess the market for a business or organizational unit.

POLITICS: The political climate in a nation determines how well a nation performs. It relates to every other factor, the economy, social and technology. In terms of politics, Nigeria Breweries Plc strategically took advantage of the ban on importation of barley, which was lifted, and a $20 \%$ tariff placed on some products by the federal government on January 6, 1998.As a result, they had more options of raw materials for production, and were forced to make use of local corn and sorghum, which they took to their advantage. This brought about cheaper raw materials, vis a vis production cost, resulting to reduction in prices of their products (Daily Trust, 11 September 2008).

ECONOMY: The economic environment consists of factors that show how an economy is developing. The country has a very high level of unemployment and underemployment, which made a lot of people idle and ironically spent most of their time at bars drinking brewery products, especially beer. This fallout, impacted positively on Nigeria Brewery Company. Another key point is the exchange rate, which is very critical for a brewery company in terms of importation of raw materials, if not locally sourced for any reason. Nigeria's Naira is not strong, as compared to the US dollar, which derives its strength from their robust economy, in fact the strongest economy in the world. This however, affects the Nigerian brewery business adversely, and then borne by the end consumer, when the raw materials are being imported at exorbitant cost. 
SOCIAL FACTOR: Social analysis has to do with factors such as demographics, class structure, gender, age, health and environmental consciousness. As a corporate citizen, Nigeria Breweries Plc has paid so much attention to corporate social responsibility(CSR).They are a socially responsible corporate Organization (corporate strategy and corporate values)which embeds a sustainability agenda which they tagged "brewing a better world (BaBW) program". This Company is involved in so many event sponsorship and one of them is star quest, which aims at discovering upcoming and new musical talents, also Big Brother Nigeria (BBNaija). Nigeria Breweries Plc also has a creative writing program meant to coach the young writers. They have "Felix Ohiwerei Education Trust Fund" which put in place a Maltina Teacher of the year award to reward performing Teachers in Nigeria. This Year, Ms Oluwabumi Anani from Concordia College Yola, Adamawa state, won the 2020 Teacher of the year award and will receive $\mathrm{N} 6.5 \mathrm{~m}(\mathrm{~N} 1.5 \mathrm{~m}$ immediately and $\mathrm{N} 1 \mathrm{~m}$ annually for the next five years).Another teacher, Idele Benedicta, from Asoro Grammar School Senior, Egor, Edo State came second, and will be handed down N1.5 Million and the third Adeeko Folukemi, a teacher from Patterson Memorial Baptist Grammar School, Abeokuta, Ogun State will receive N1, 250.000.00. Another N500,000 will be given to 27 teachers who were their state's champion. Nigeria Breweries Plc, gets value in doing this, as it can be regarded as a form of competitive parity, they budget yearly to match other companies like the banks etc for CSR and other helping hand projects. However, looking through their2017 - 2017 annual reports and accounts, there was no disclosure of her social responsibility accounting information, as compared to some other companies like Fidelity bank, First bank and United Bank for Africa. This is a low point on their part, as a publicly quoted company needs to disclose all information for the sake of transparency and avoidance of trust deficit. Surprisingly, it did not stop their enhanced financial performance comparatively, as this came as a result of their social responsibility culture. But the 2019 annual report, showed clearly how socially responsible Nigeria Breweries Plc is. The corporate social responsibility and sustainability reports, highlighted 6 focus areas," Every drop, protecting water resources, Drop the $\mathrm{C}$, reducing carbon emission, promoting health and safety, Advocating responsible consumption and growing with the communities"

TECHNOLOGY: Businesses are affected by changes in technological environment. Although, Technology is not a forte for Nigeria Breweries Plc, but focused more on investing in beer making equipment. That is another strategic marketing maneuver used to make their company more competitive. I would advise they innovate more to improve their performance and remain a market leader.

\section{PORTER'S FIVE FORCES MODEL}

Another critical winning strategy, to look at here is Porter's five forces model. It is the frame work used for analyzing competition in a business environment. It also determines the competitive intensity and therefore, the attractiveness of an industry in terms of profitability. At the heart of this model, is Industry rivalry i.e. Nigeria Breweries Plc, and existing competitors in the sector, threat of new entrants, bargaining power of buyers and Suppliers and the threat from substitute goods of competitors. 
POTENTIAL ENTRANTS: This has to do with threat of new entrants coming to compete for market share in brewery industry. In this sector, the potential entrants coming into the industry in Nigeria may not find it easy, due to the processes involved, which may be cumbersome. These are mostly policies of government, the cost of exit and entrance which puts Nigeria Breweries Plc at a comfortable position as market leader and also a loss Leader. However, it may seem good for the company at this stage, but the extension of this kind of hurdle to other industries or general business environment in Nigeria may deter foreign direct investment. And can create monopolistic tendencies, which will result to low quality drinks, as competitiveness has been reduced to minimal levels. Another discouraging issue new entrants may have, is difficulty of the switching cost, for local and international companies wanting to establish in this sector. The associated costs may be really high, as a result of difficulty in discovering new suppliers of raw materials, given that Nigeria Breweries Plc has been around for a while and very established in Nigeria.

SUBSTITUTES: Substitute products refer to products in other industries. To the economist, a threat of substitutes occurs when a product's demand is affected by the price change of a substitute product. Finding a substitute for beer in Nigeria is practically impossible because drinking beer in Nigeria has become part of social activity and also with the affordable price for the average and low income earners (a bottle of star larger beer costs N140, which is less than a pound and is cheaper compared to wine, brandy and other bottled alcoholic drinks).It has a competitive advantage over other types of drinks, like wine and brandy but not competitive parity which has to do with budgeting and spending for the purpose of promoting your brand name, not necessarily to beat competition. The only major competitor within the industry that Nigeria Breweries Plc has in beer production, is Guinness Nigeria Plc and both companies have between them $77 \%$ market share, therefore, it would only take a special brand to substitute either of these brands. They can decide to adopt mergers and acquisition strategy, where they can merge or one acquiring the other to substantially suppress competition to own a substantial market size.

BARGAINING POWER OF BUYER: The bargaining power of the buyer has to do with consumer's expectation on businesses to provide better quality products, increased level of customer service, and competitive pricing. Buyers can use their bargaining power to control an industry, by ensuring competitive pricing and reduce the profitability level of the seller in any particular industry. Given the mad rush for Nigeria Breweries Plc drinks as hinted previously in this write up, how it has become a social event to 'hang out' and drink beer with friends, it has reduced the buyer power without their knowing it. They have a subtle or semi monopolistic power given the quality of their drinks. This company is a household name, and was made possible due to their being the first to start business in Nigeria, production of high quality drinks, their social corporate responsibility and helping hand project drive, has popularized them and enhanced their growth in the country. Consumer's very strong brand loyalty was made possible because of these factors just mentioned.

BARGAINING POWER OF SUPPLIER: The explanation of the power of the supplier is when you have one or few supplier of goods which is needed by the consumer. In this case, Nigeria Breweries Plc has a subtle monopolistic power in an oligopolistic market, which 
naturally has given it high supplier power, the limited availability of barley and other substitutes for brewing of beer has put them in a good stead. Given the austere nature of Nigeria economy, the farmers and suppliers of these raw materials, are desperately in need of money and may not use their power to control prices as they wish, leaving this beer company at their mercy. However, before this situation gets to the stage where providers of these materials may chop and change prices, the way they want, Nigerian Breweries Plc can avert it by going into farming for its raw materials, as a form of backward integration strategy.

RIVALRY: Nigeria Breweries Plc controls about77\% share of their market, as a result of its stability in the market."Rivalry is also low because there are only two major market Leaders in the industry, so it has enough market for both of them and it can gear its strategies against only one major competitor" (Oyeyinka, 2002).

\section{THE COMPETITION FOR NIGERIA BREWERIES PLC}

As indicated before, the major competitor for Nigeria Breweries Plc is Guinness limited Nigeria. It manufactures beer in the brand name of "Harp" in Nigeria. Harp Lager Brewery is located at Ikeja, Nigeria. This Nigerian brewery company belonging to Tony Joyce started production in 1981.It's annual production of beer is about 1,500,000 hl. The other beer production units of Guinness Nigeria Limited are located in Agbara, Benin in Edo and Aba in Imo. The other little breweries are not strong enough to give Nigeria Breweries Plc a stiff competition. In general, competition for Nigeria Breweries Plc is minimal as its only major competitor is Guinness Nigeria limited. Nigeria Breweries Plc has an edge over these competitors, it has adopted so many strategies like the competitive parity method, where it sets out to make itself a house name, enhance its brand name, without trying to dislodge competitors plus being a socially responsible company etc This has obviously made consumer behaviour very predictable, as there is always repeat purchase of their products. It is a going concern, producing beer amongst others for over 60 years, no wonder there is no trust deficit with regards their products. It also has a lot of branches all over Nigeria for easy reach to its customers all over the country.

MARKETING STRATEGY: Marketing strategy is a short term, long term and also forwardlooking plan of an organization or businesses who tries to gain competitive advantage by satisfying customer needs. Nigeria Breweries Plc has remained a market leader, because it has consistently been strategic in their marketing maneuvers, which has helped them to sustain competitive advantage when it wants, as against competitive parity. It has overtime used factors such as market segmentation, targeting and positioning to carve out a niche in brewery industry and increased market share.

SEGMENTATION: Segmentation of the market is dividing the market that is heterogeneous into homogenous groups based on parameters like geographic, demographic, psychographic and behavioral, benefit segmentation, ethnic segmentation, age, gender, life style, social class, personality and Income distribution (Jobber, 2007). Nigeria Breweries Plc serves customers at all levels of the society and those above 18years as legally accepted by policy. Recall, that in the Southern part of Nigeria drinking of beer is a social event, and the low price of the beer product, has led to increased purchase by all classes of the society, no matter what they earn. A critical 
success factor for a successful business is good advert techniques, which are needed to promote a company's goods and services. The advertisement this company has put out to the public, has gained traction over the years and has appealed to all age groups. It has stayed in people's subconscious. Nigeria Breweries Plc has advertised their major beer product (Star) as a drink that delivers superior enjoyment and brightens all social occasions, and this is so because, the drink is seen as a key to happiness and celebration byconsumers. Nigeria Breweries Plc strategy of having all their products in every market segment has helped the company grow and has become a house hold name.

TARGETING: Targeting is the process of ascertaining the most important market segment, where marketing efforts can be directed for profitable purposes (Keegan, 2001). This strategy is what Nigeria Breweries Plc used, targeting different market segments to sell their beers. They used differentiated target strategy where each segment used a different strategy.For example,they had two of their beer products targeted towards two groups. The "Star" beer product targets the youth, evidenced in most of its advertisements and sponsorship programs, which was usually directed towards the millennials, generation $\mathrm{Y}$ and $\mathrm{X}$ ennials, while the "Gulder" beer product targets generation X, older and high financial class of people, this is also evident in its own type of advertising methods tilting towards competitive parity and its sponsorships.

POSITIONING: Positioning refers to the place that a brand occupies in the minds of the customers and how it is distinguished from the products of the competitors. Nigeria Breweries Plc has many brands which include Star, Gulder, Legend, Heineken, Maltina, Amstel Malta, Fayrouz, Climax, Goldberg, Malta Gold and Life, which are mainly sold Internationally, in Nigeria and other countries that border us. But the two major brands are Star and Gulder drank mainly by the millennials, generation $\mathrm{Y}$ and $\mathrm{X}$ ennials, while the older generations and seniors drink Gulder. These brands are produced and positioned in a way that customers by their perception, identify with these products. It is noteworthy, that Gulder which is bitter is consumed by the older generation, and helps them run away from sugar.

\section{MARKETING MIX}

This is a strategic controllable and tactical marketing tool, a company uses to produce a desired response from its target market. It consists of everything that a company can do to influence demand for its product. The marketing mix are now 7Ps, Price, Promotion, Product, Place, packaging, positioning and people, but for this study, we will look at the 4Ps, which are Price, Promotion, Product and Place.

PRICE: The price of the product (Star beer) produced by Nigeria Breweries Plc is affordable for all the consumers in the market because it is produced from local corn and sorghum which is cheap, so they make their profit and satisfy the customers. The consumers here, are mostly the youth and since most of their sales are mostly made for youth, the price would always remain affordable so as not to lose customers and reduce sales.

PRODUCT: Nigeria Breweries Plc has other products, which are more than enough for the market, but Gulder and Star stands out, because of the groups they serve. Sometimes, they are 
taken in place of water which adds to huge sales, impacting positively on the company's bottom line. Nigeria Breweries Plc is lending helping hand to teachers yearly, known as "Maltina teacher of the year award".

PLACE: This term really refers to "anywhere the customer can obtain a product or receive a service" (Jones, 2007). Nigeria Breweries Plc, has a wide distribution channel and makes use of external companies, for distribution of its products nationwide. They use other transportation companies to assist distribute their goods nationwide. This system of distribution helps make the product readily available to the consumers, but this however limits direct contact between producer and consumers, which affects feed-back mechanism, as turnaround time is important to satisfying customer needs.

PROMOTION: Promotion decisions are used to find the appropriate and effective method to promote a particular product, and to increase sales in the market place. Amongst the effective method, is the competitive parity method. It is a means to make the public understand your product on offer and services. There are about 5 main types of promotion mix which are advertising, personal selling, public relations, direct marketing etc. Promotion can be seen as "a way of closing the information gap between would-be sellers and would-be buyers". (Jones, 2007)

Nigeria Breweries Plc, promotion strategy is executed through consumer sales promotion targeted at the final consumer market plus targeting the wholesalers and retailers of the products through trade sales promotion. The fallout of this sales promotion is awareness of the customers, which will lead to increased sales. Examples of their sales promotions are "Star Xmas Carnival" which was targeted at the company's retailers and consumers were prizes like bags of rice, DVD Players and other items were won by consumers each day for 21 days (Ekeh, 2009), Gulder ultimate search where the winner took home 3million naira cash prize (Ajayi, 2004).

\section{EVALUATION OF STRATEGY AND TACTICS}

Given that Nigerian Breweries Plc has been around for over 60 years, and also a market leader tells, it is a going concern. Evidently, they are doing the right things in the market place and their strategy has worked so far. Competitive analysis helps every company that wants to succeed. The information obtained on continuous basis has made them to severally re-brand, product development where they create, enhance, improve and innovate their products. It was in 2006 that, they launched its Gulder Max brand which was a darker, richer version of the successful Gulder Lager. And in trying to capture and stay strong in the market, by producing soft drink to enter the market, it hit the market with a fresh drink known as Farouz brand of soft drinks. Another marketing strategy they came with, was the repackaging of Maltina drink, where they introduced a larger size of bottle, while keeping the price of the former smaller bottle. The almighty Star beer brand was also rebranded and made a lot of sales, as the older folks have already identified with the product. 


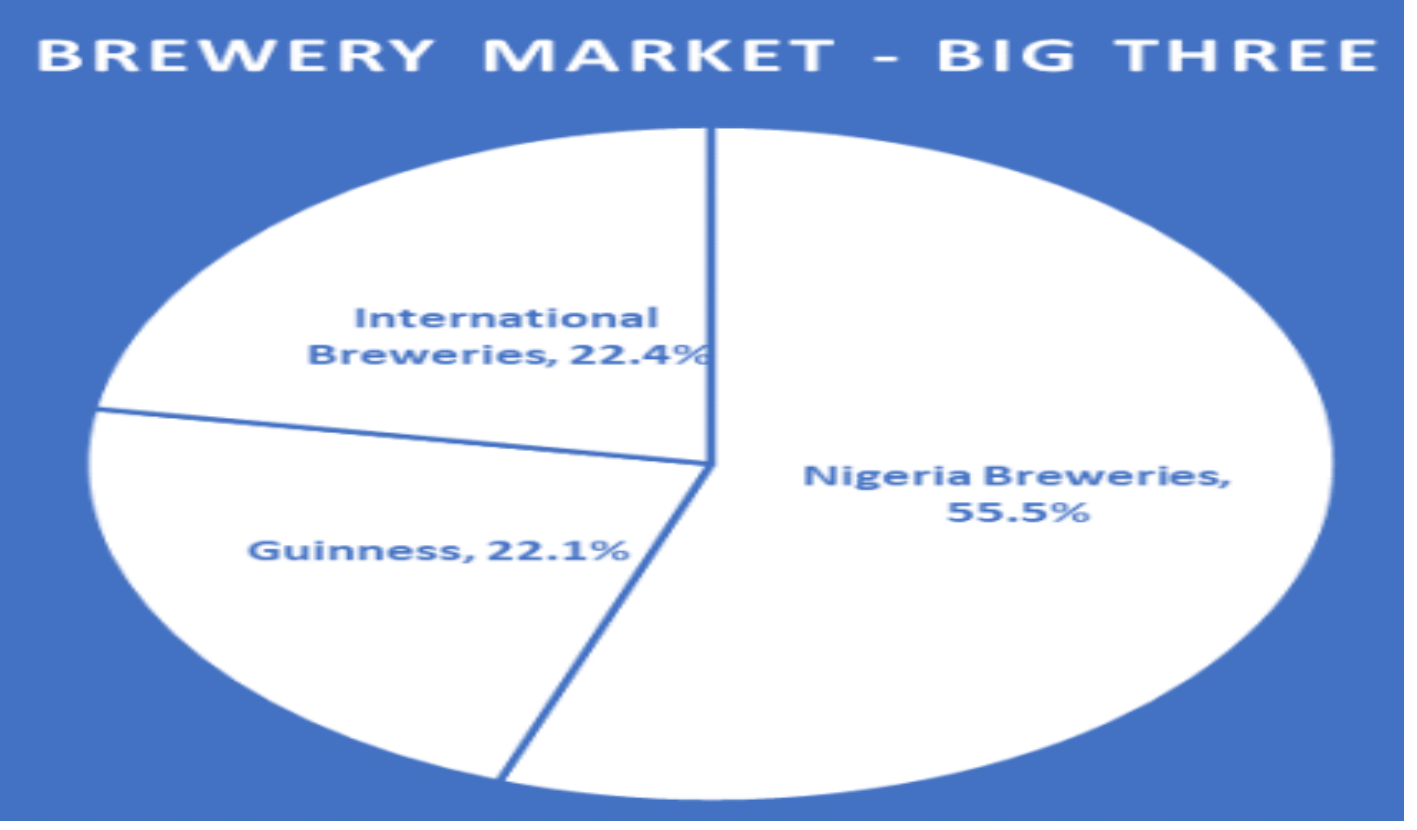

Figure 1: Market Share of Top Brewery Brands in Nigeria

Comparative data from the financial statements of three of the largest beer makers in the country suggest that Guinness Nigeria Plc has lost its place as the second-largest brewery by revenues to International Breweries. As at the half-year ended December 2018, Guinness Nigeria reported revenues of about N67.79 billion, compared to N70.5 billion in the same period a year earlier. International Breweries, on the other hand, reported half-year revenues for the period ended June 2019 of N68.6 billion, slightly overtaking its rival. Nigeria Breweries still leads both companies, with half-year (January to June 2019) revenues of N170.1 billion. The Media facts report of Media Reach shows that Nigerian Breweries spent over N2 billion on above the line (ATL) advertising activities (television, billboards, radio and magazines/newspapers) in 2016. Guinness Nigeria's advertising spend in the same period was over N700 million, while AB InBev, a fairly new entrant at the time, spent N300 million on ATL advertising, mostly on billboards.

\section{CONCLUSION AND RECOMMENDATIONS}

Nigeria Breweries Plc has made major inroads in the Nigeria and international market, which dates back to 1986 with current export destination being United States of America, United Kingdom, Netherlands, Canada and some parts of Middle East. Nigeria Breweries Plc, cannot be left out in the first five brewery companies in Nigeria and this study shows their strategies and tactics, which explains the reasons why they are such a major force in the brewery industry in Nigeria. They have used the competitive parity model as defensive strategy to protect their brand name, reputation, and repositioned without over spending and over trading. Nigeria Breweries Plc can be more strategic by growing its own material inputs to prevent any unforeseeable instability and threat that may arise from suppliers of such resources. 
Therefore, other brewery companies looked at, even though not in detail as a result of my limitations have also been successful, using marketing critical success factors vis a vis the competitive parity method, as Nigeria Brewery Plc, has led the pack.

As recommendation, there is need for them to continuously check the performance of their products internationally, and other parts of Africa, and also see any strategic location they have left out, so as to improve reach of their products vis a vis organizational growth. They can diversify into other brands that will be liked abroad to broaden and expand their market base. This they can do by sending experts who will do a proper analysis of these markets, understand the demands of the market and produce to standard. Technology cannot be traded for anything else, if you want to grow and remain in business. Free Installation and location of vending machines at strategic points at their distributor companies, will help them market convenience and efficiency of their products locally is key. They should not lose sight of originality of any of their products. Espionage may be critical in this case, to compete effectively. 


\section{REFERENCES}

Abdel-Dayem., H., \& Safaa, M. (2001). Toward a proposed framework for the management competitive parity in the modern manufacturing environment. The scientific journal of the economics and Commerce - Ain Shams University, VI ( ${ }^{\text {rd }}$ Ed. $), 470$ - 477

Adekoya, F. (2016). Nigeria: Brewery industry as driver of value-chain investments. The Guardian News Paper, p 45. Retrieve on 7th December 2020, from. allafrica.com/stories/201602101374.html

Adeniji, S. (2017). Impact of competitive parity on competitive advantage in the manufacturing industry: A study of selected manufacturing firms in Nigeria, International Journal research in Accounting, Finance and Management science, 4(3), 97-108.

Al-Awawdeh, W. M., \& Al-Sharairi, J. A. (2012). The relationship between competitive parity and competitive advantage of Jordanian Private Universities, International Journal of Business and Management, 7(8), 123 - 142.

Arokolaei, A. M. (2013). Studying the obstacles of applying a competitive parity system in firms accepted in Tehran Stock exchange, Journal of Economics and International finance, 5(1), $17-20$.

Baharudin, N., \& Jusoh, R. (2015).Target Strategic management (TCM): A Case Study of an Automotive Company. Contemporary Issues in Management and Social Science Research. 172(January). 525-532.

Baharudin, N., \& Jusoh, R. (2015). Target Strategic management (TCM): A Case Study of an Automotive Company, Procedia - Social and Behavioural Sciences 172 (January), 525 532

Bennett L A., Carlos, C, M.D, Chandrashekar, M.D and Oye G, (1998). Alcoholic Beverage Consumption in India, Mexico, and Nigeria, A Cross-Cultural Comparison.

Briciu, S., \& Capusneanu, S. (2013). Pros and cons for the implementation Competitive parity Method in Romanian Economic Entities, Accounting and Management Information System, 12(3), 455-470.

Chartered Institute of Management Accountants (2005). Competitive parity in the NHS, Retrieved on Novermber 30, 2020 from http://www.cimaglobal.com/cps/rde/xbcr/SID0AE7C4D1.

Clifton, B. C., Bird, H. M. B., Albano R. E., \&Townsend,W. P. (2004). Competitive parity: Market driven product design, New York: Marcel Dekker, Inc. 


\section{Article DOI: 10.46654/ij.24889849.b61214}

Comfrey, A. L., \& Lee, H. B. (1992). A first course in factor analysis. Hillsdale, New Jersey: Lawrence Erlbaum Associates.

Cooper, R., \& Kaplan, R.S. (1992). Implementing activity-based strategic management. Montvale, NJ: The Institute of Management Accountants. Avaliable at: https://searchworks.stanford.edu/view/10041213.

Dekker, H., \& Smidt, P. (2003). A survey of the adoption and use of competitive parity in Dutch firms, International Journal of production Economics, 84(3), 293-305.

Ekeh, D, Brand review: Consumer promotion as key driver, The Guardian Newspaper.3 January 2009.

Ellarm, L. (2000). Purchasing and supply management's participation in the competitive parity process, Journal of supply chain management, 36(2), 39-45.

Ellarm, L.(2006). The Implementation of Competitive parity in the United States: Theory Versus Practice Journal of supply Chain Management, 42(1), 13-26.

Essential Guide to Marketing Planning / Marian Burk Wood.

Ghafeer, N. A. M., Abdul-Rahman. A. A. A., \&Mazahrih, B. J. (2017). The impact of target cost method to strengthen the competitiveness of industrial companies, International Journal of Business and Social Science, 5(2), 250 - 263.

Helms, M. M., Ettkin, L. P., Baxter, J. T., \& Gordon, M. W. (2005). Managerial Implications of Competitive parity, Competitiveness Review, 15(1), 49-56.

Henrik, B., \& Gustav, F. (2003). The use of competitive parity in Swedish manufacturing firms. (Doctoral dissertation in Management Accounting). School of Economics and Commercial law, Goteborg University. Retrieved on $12^{\text {th }}$ November, 2015 from: https://gupea.ub.gu.se/.../1/03-04-3D.pdf

Horváth, P. (1993). Competitive parity: State of the art report. Arlington, Texas: Computer aided Manufacturing International (CAM-I).

Hussein, N. O., \& Sulaiman, S. (2017). Competitive parity Evolution: A Review of the Literature from IFAC's, Asian Social Science, 10(9), 82-99.

Idown, A. S. (2017). Impact of Competitive parity on Competitive Advantage in the Manufacturing Industry: A Study of Selected Manufacturing Firms in Nigeria, International Journal of Academic Research in Accounting, Finance and Management Sciences 4(3), $97-108$. 


\section{Article DOI: 10.46654/ij.24889849.b61214}

Imeokaparia, L., \& Adebisi, S. (2017). Competitive parity and performance of manufacturing industry in south-western, Nigeria, Global Journal of management and business research, 14(4). $51-57$.

Institute of Management Accountants (1994),Implementing competitive parity: Statement on management accounting, Publication Number 98377.

Jalaee, H. (2012). Advantages of Competitive parity in Organization, International Journal of Research in management, 2(1), 10-18.

Jobber, D, (2007), Principles and Practice of Marketing, 5th edition; Maidenhead McGraw-hill Education.

Jones, S, (2007), Exploring corporate strategy: text \& cases. 8th edition.

Kaur, M. (2017). Poising between price and quality using competitive parity, GE - International Journal ofManagement Research, 2(1), 17-33.

Kocsoy, M., Gurdal, K., \&Karabayir, M. E. (2008). Competitive parity in Turkish Manufacturing Enterprises, European Journal of Social Sciences, , 7(2), 92-105.

Kumar, A. (2017). Association of quality function deployment and competitive parity for competitive market. GE - International Journal of Management Research, 2(2), 24-35.

Malandrakis, S, (2009). Nigeria Spearheads Optimistic Outlook for Beer Sales in sub-Saharan Africa, Euro Monitor

Maria, M, A. (2012). Cost measurement and strategic management in competitive parity,Annals of Faculty of Economics 1(1), 533-547.

Maskell, B., \& Baggaley, B. (2003). Practical lean accounting: A proven system for measuring and managing the lean enterprise, New York: Productivity Press.

Moschis, P. G, (1993). Life Stage Segmentation for Marketing Strategy Development.

Murat, K., Kadir, C., \& Mehmet, E. K. (2009). Competitive parity in Turkish manufacturing enterprises, Problems and Perspectives in Management, 7(1), 197 - 207.

Nigerian Tribune, 8th June 2009.

Obike,U,(2005).Nigeria Breweries Continues to Expand Market Share; This Day Newspapers.

Olabisi, J., \& Dafe, P. O. (2017). Implementing Competitive parity in Small and Medium Scale Enterprises in Ogun Industrial Metropolis, International Journal of Humanities and Social Science, 4(8), 223- 233. 
Oldroyd,M,(2004).CIM Revision Cards, Marketing Environment; Butterworth Heinemann.

Oyeyinka, O, B,(2002).Manufacturing Response in a national system in Nigeria, The United Nations University.

Pazarceviren, S .Y., \& Celayir, D. (2013). Competitive parity based on the activity-based costing method and a model proposal. European Scientific Journal. 4(Special edition), 1-21

Razaq, A. (2010, October 10). Nigerian breweries sector update: Brewing growth and malting value. Vetiva Research, 2010. Retrieved on $5^{\text {th }}$ December, 2020 from: https://www.proshareng.com/.../VetivaBrewerySectorUpdate2010Brewin.

Sterling Capital market (2010) stock analysis/recommendation breweries sector. Retrieved from http://www.sterlingcapitalng.com/uploads/stock recommendation- 26 july,2010.Equity research $23^{\text {rd }}$ July 2010.Pdf

Subhash, C. J. (1994). Global competitiveness in Beer industry: A case study, Food marketing Policy centre research report no. 28. University of Connecticut, Sorrs, USA. Retreived on $29^{\text {th }}$ January, 2016 from: ageconsearch.umn.edu/bitstream/25161/1/rr940028.pdf.

Sulayman, H. (2017). The adoption and implementation of competitive parity approach in manufacturing, International Journal of Business and Social Science, 5(6), 72-81.

Ulrich R, Mc Donald M.C and Shellhamer, L,(2002). Promoting Brand Benefits; The role of consumer Psychographic and lifestyle. Journal of consumer marketing.

Vanguard, 5 June 2003, Nigeria Breweries Consolidates Corporate Leadership; Africa New.

Vasile, E., \& Croiteru, I. (2013). Target cost-tool for planning, managing, and controlling costs, Romanian Journal of Economies/ Institute of National Economy, 36(1), 114-127.

Wang W,(2009).Managing Customers and Markets; Salford Business School.

Wu, C. L., Huang, P. H., \& Brown, D. (2013). Competitive parity as a role of strategic management accounting in real-estate investment industry, African Journal of Business Management, 7(8), 641- 648.

Yin, R. K. (2003). Case Study Research - Design and Methods (3rd ed.), California: Sage Publications.

Zengin, Y., \&. Ada, E. (2010). Strategic management through Product Design: Competitive parity Approach, International Journal of Production Research, 47(19), 5593 -5611. 
International Journal of Advanced Academic Research (Business and Economic Development) | ISSN: 2488-9849

Journal DOI: 10.46654/ij.24889849

Vol. 6, Issue 12 (December, 2020)| www.ijaar.org

Article DOI: 10.46654/ij.24889849.b61214

Zimina, D., Ballard, G. \& Pasquire, C. (2012). Target value design: using collaboration and a lean approach to reduce construction cost, Construction Management \& Economics 30(5), $383-398$. 